\title{
Development of an empirical formula for estimation of bioretention outflow rate
}

\author{
Sezar Gülbaz' ${ }^{1}$ Cevza Melek Kazezyılmaz-Alhan ${ }^{1 *}$ and Rasim Temür ${ }^{1}$ \\ ${ }^{1}$ Civil Engineering Department, Istanbul University-Cerrahpaşa, Avcılar, Istanbul, 34320, Turkey
}

\begin{abstract}
Urbanization of a watershed affects both surface water and groundwater resources. When impervious area increases, the excess runoff and volume of water collected at the downstream end of the watershed also increases, due to the decrease in groundwater recharge, depression storage, infiltration and evapotranspiration. Low-impact development (LID) methods have been developed in order to diminish adverse effects of excess stormwater runoff. Bioretention is one of the LID types which is used to prevent flooding by decreasing runoff volume and peak flow rate, and to manage storm-water by improving water quality. In this study, an empirical formula is derived to predict the peak outflow out of a bioretention column as a function of the ponding depth on bioretention, hydraulic conductivity, porosity, suction head, initial moisture content and height of the soil mixture used in the bioretention column. Coefficients of the empirical formula are determined by using metaheuristic algorithms. For analyses, the experimental data obtained from rainfall-watershed-bioretention (RWB) system are used. The reliability of the empirical formula is evaluated by calculating the absolute per cent error between the peak value of the measured outflow and the calculated outflow of the bioretention columns. The results show that the performance of the empirical formula is satisfactory.
\end{abstract}

Keywords: bioretention, low impact development (LID), excess runoff, stormwater management, empirical formula

\section{INTRODUCTION}

Land development and increase in urbanization of a watershed affect both surface water and groundwater resources. With new developments, the impervious area of a watershed increases which results in excess runoff and volume of water collected at the downstream end of the watershed. Low impact development / best management practices (LID/ BMPs) such as bioretention facilities, vegetated rooftops, rain barrels, vegetative swales and permeable pavements, have been developed in order to diminish the adverse effects of urbanization (Yang et al., 2013; Sigmon et al., 2013; Gülbaz et al., 2017). LID/BMPs are a land use planning method which may be used to manage stormwater runoff in order to reduce flooding as well as simultaneously improve water quality. Bioretention is one of the most frequently used LID/BMPs implementation (Liu et al., 2014; Gülbaz and Kazezyılmaz-Alhan, 2017a) in flood prevention and pollutant removal (Birch et al., 2004; Makropoulos and Butler, 2010). Bioretention is used to decrease runoff volume and peak flow rate, increase evapotranspiration, infiltration and groundwater recharge, and reduce the pollutant loading in surface and groundwater (Hunt et al., 2006; Davis, 2008; Endreny and Collins, 2009; Li and Davis, 2009; Li et al., 2009; Brown and Hunt, 2011; Gülbaz and Kazezyılmaz-Alhan, 2017b; Gülbaz and Kazezy1lmaz-Alhan, 2017c).

There are experimental studies in the literature which present the capacity of bioretention in stormwater runoff reduction. For example, Hunt et al. (2008) showed that peak flow reduction is between $96.5 \%$ and $100 \%$ after bioretention implementation. Hatt et al. (2009) reported that at least $80 \%$ peak flow reduction was observed after bioretention implementation in their study. DeBusk and Wynn (2011) obtained $99 \%$ peak flow reduction by using $88 \%$ sand, $8 \%$ fines, $4 \%$ organic matter in their bioretention cell. Olszewski and Davis (2013) obtained 83\% peak flow reduction by using $54 \%$ sand and $46 \%$ fines in their bioretention study. Measurement and estimation of peak flow at the outlet of bioretention cells are necessary in order to evaluate their peak flow reduction performance. Therefore, investigation of peak flow estimation techniques is required in bioretention studies. Optimization methods such as meta-heuristic algorithms are helpful tools to discover an empirical formula for prediction of peak flow at the outlet of bioretention systems. Metaheuristic algorithms have been successfully applied to a wide range of engineering optimization problems (Yang, 2010). However, to our best knowledge, meta-heuristic algorithms have not been used in peak flow prediction out of bioretention systems.

In this study, an empirical formula is derived to predict the peak outflow from a bioretention column. In this derivation, the parameters which define the bioretention characteristics, such as hydraulic conductivity of the bioretention soil, suction head, ponding depth, porosity, initial moisture content and bioretention soil thickness, are used that affect the peak value of the outflow hydrograph at the exit of the bioretention system. Eight different optimization algorithms are used in determining the coefficients of the empirical equation. Results of previous experiments are used as input data for the analyses. Then, performance of the empirical formula is evaluated by comparing the experimental results (Gülbaz and Kazezyllmaz-Alhan, 2017a) collected in the RWB system with the calculated results using the empirical equation. Results show that the formula can be used to estimate the peak of the bioretention outflow.

\footnotetext{
* To whom all correspondence should be addressed.

e-mail:meleka@istanbul.edu.tr

Received 19 March 2018, accepted in revised form 8 March 2019.
} 


\section{MATERIALS AND METHODS}

\section{Experimental setup: rainfall-watershed-bioretention (RWB) system}

An experimental setup including a synthetic rainfall system, drainage area and bioretention columns was constructed on Avcılar Campus of Istanbul University-Cerrahpaşa in Istanbul, Turkey. The experimental setup is called the rainfall-watershedbioretention (RWB) system (Gülbaz and Kazezyılmaz-Alhan, 2017-a). The system contains $40 \mathrm{~m}^{2}$ of drainage area for watershed simulation, 40 rainfall nozzles for artificial rainfall simulation and 4 bioretention columns. The drainage area has $10 \mathrm{~m}$ length and $4 \mathrm{~m}$ width and was constructed $180 \mathrm{~cm}$ above the ground level. The artificial rainfall system was constructed $1 \mathrm{~m}$ above the drainage area to simulate rainfall with different intensities. A water tank with $5 \mathrm{~m}^{3}$ capacity and a pump are used for the artificial rainfall system setup. The pump, valve, pressure gauge and flow meter are connected to the rainfall system. A schematic of the RWB system (a) and a photograph of the RWB system (b) are shown in Fig. 1.

\section{Bioretention columns}

The bioretention columns had a cylindrical shape with surface area of $2290 \mathrm{~cm}^{2}$ and height of $124 \mathrm{~cm}$ and were made from polyethylene material. Bioretention columns consisted of gravel, a mixture of sand and local soil, mulch and plants. Plants, mulch and gravel were the same for all bioretention columns. However, local soil and sand ratios were varied in order to observe the
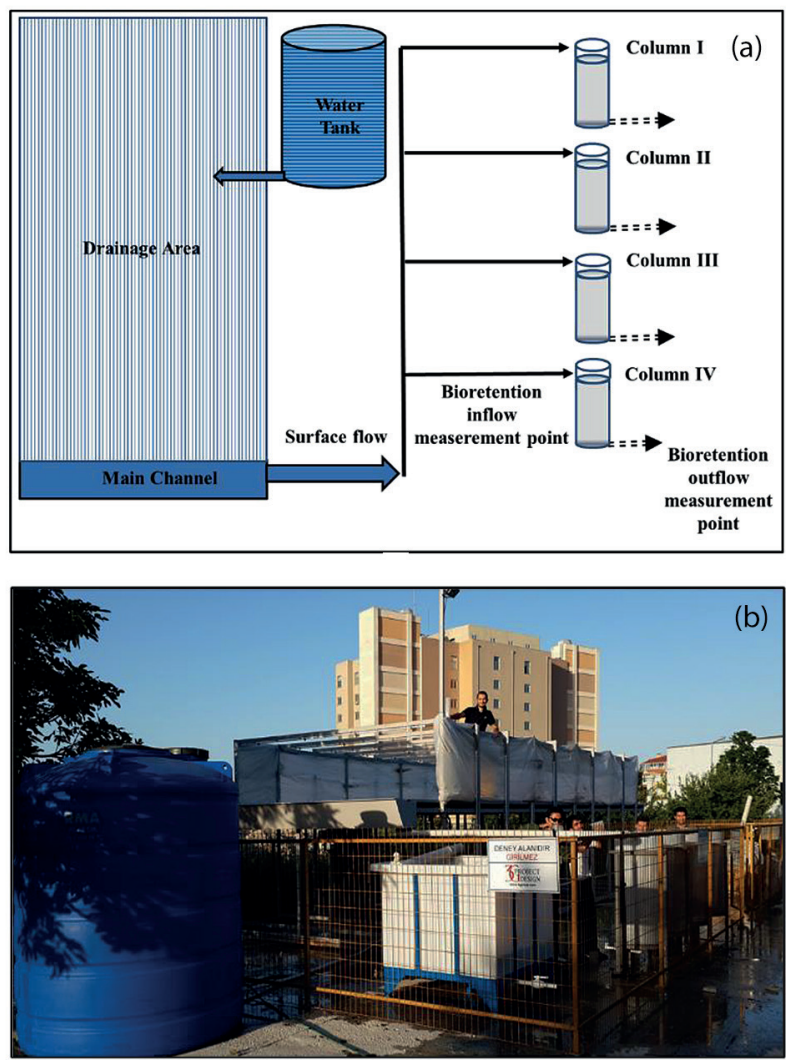

Figure 1

Rainfall-watershed-bioretention (RWB) system (a) schematic (modified after Gülbaz and Kazezyllmaz-Alhan, 2017a); (b) photograph effects of local soil to sand ratios. Figure 2 shows the content and dimensions of each layer of the bioretention columns.

Based on the experimental observations, one can argue that bioretention outflow is directly related to the hydraulic conductivity, suction head, initial moisture deficit, and ponding depth, and inversely related to the thickness of the soil in the bioretention system. If the values of these parameters increase, the amount of drained water at the exit of the bioretention system also increases. Contrary to this, when the initial moisture content and thickness of the soil in the bioretention system increase, the outflow rate decreases. Based on this physical behaviour of the bioretention system, the structure of the empirical formula is developed. Then, some empirical coefficients are introduced into the formula. The most satisfactory values for the empirical coefficients are obtained by using 8 different optimization algorithms.

The parameters listed above and used in the empirical formula development for peak outflow prediction were measured during the experiments (Gülbaz and KazezyllmazAlhan, 2017a). Only the suction head is selected within the range given by EPA SWMM manual (Rossman, 2010) based on the local soil characteristics. The surface runoff generated over the drainage area reaches the bioretention columns as inflow; infiltrates through the bioretention soil, and drains out of the bioretention column as outflow. The bioretention outflow shown in Fig. 3 was measured in the RWB experimental setup and used in empirical formula development. The parameters of each bioretention column are given in Table 1. Furthermore, the measured maximum ponding depth values for each bioretention column are given in Table 2 (Gülbaz and

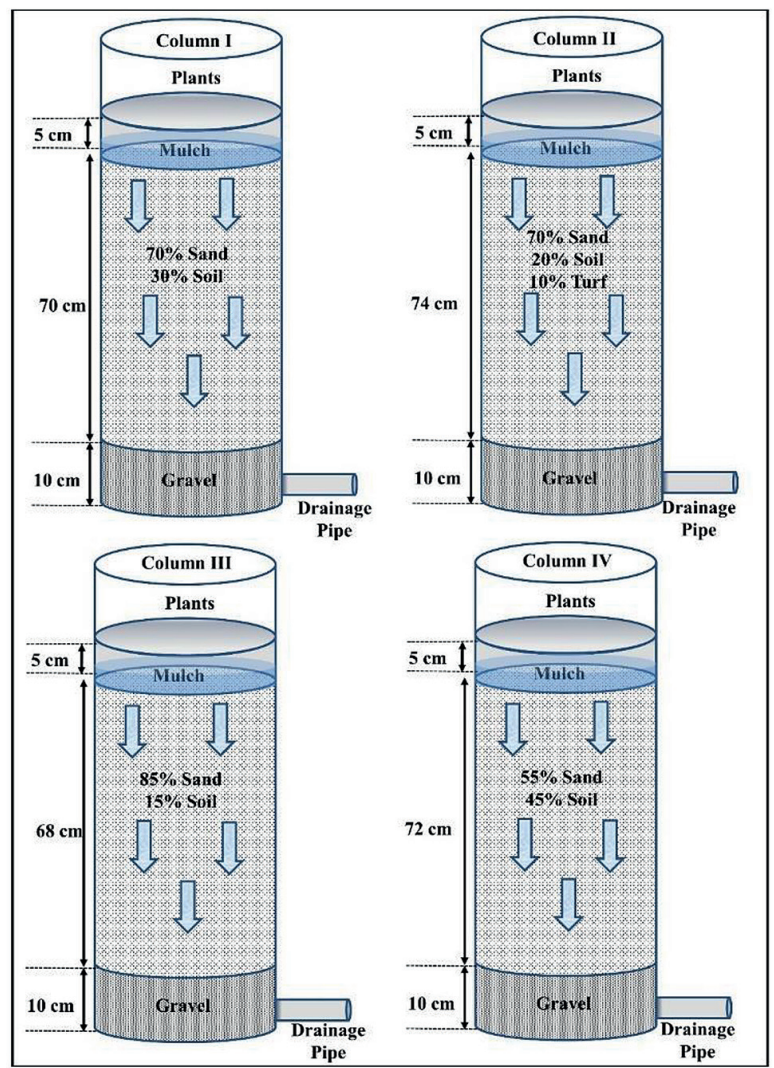

Figure 2

Schematic of 4 bioretention columns used in RWB system (modified after Gülbaz and KazezyIImaz-Alhan, 2017a) 


\begin{tabular}{|l|c|c|c|c|c|}
\hline \multicolumn{7}{|c|}{$\begin{array}{c}\text { TABLE 1 } \\
\text { Parameters used in the empirical formula } \\
\text { (Gülbaz and Kazezyılmaz-Alhan, 2017a) }\end{array}$} \\
\hline Column No. & $\boldsymbol{K}(\mathbf{c m} / \mathbf{m i n})$ & $\boldsymbol{s}(\mathbf{c m})$ & $\boldsymbol{n}$ & $\theta_{\boldsymbol{s}}$ & $\boldsymbol{L}_{\text {bio }}$ (cm) \\
\hline I & 0.50 & 15 & 0.47 & 0.31 & 70 \\
\hline II & 0.38 & 17 & 0.46 & 0.41 & 74 \\
\hline III & 0.63 & 19 & 0.45 & 0.18 & 68 \\
\hline IV & 0.23 & 27 & 0.48 & 0.43 & 72 \\
\hline
\end{tabular}

KazezyılmazAlhan, 2017a). In this table, different ponding depths measured under 16 artificial rainfall events including 4 rainfall intensities and 4 rainfall durations are shown. Four rainfall intensities of $16,23,27.5$, and $34 \mathrm{~mm} / \mathrm{h}$ were repeated for 4 different rainfall durations, $15,20,25$, and $30 \mathrm{~min}$, in order to observe the effect of duration in addition to the intensity of rainfall on bioretention outflow. Rainfall intensity and duration are not included directly in the empirical formula. However, it is observed that rainfall intensity and duration affect the ponding depth and ponding depth is involved in the empirical formula which allows for inclusion of rainfall characteristics indirectly. A total number of 64 ponding depths were measured during the experiments and are given in Table 2. 48 ponding depth data were used to determine the empirical coefficient in the formula and 16 ponding depth data were used to validate the formula.
TABLE 2

Measured maximum ponding depth values for each bioretention column (Gülbaz and KazezyılmazAlhan, 2017a)

\begin{tabular}{|c|c|c|c|c|c|}
\hline \multirow{3}{*}{$\begin{array}{l}\text { Rainfall } \\
\text { intensity } \\
i(\mathrm{~mm} / \mathrm{h})\end{array}$} & \multirow{3}{*}{$\begin{array}{c}\text { Rainfall } \\
\text { duration } \\
\operatorname{tr} \text { (min) }\end{array}$} & \multicolumn{4}{|c|}{ Maximum ponding depth $h_{p}(\mathrm{~cm})$} \\
\hline & & \multicolumn{4}{|c|}{ Column No. } \\
\hline & & $\mathbf{I}$ & II & III & IV \\
\hline \multirow{4}{*}{16} & 15 & 7.50 & 8.00 & 1.00 & 8.50 \\
\hline & 20 & 9.00 & 11.50 & 4.00 & 12.50 \\
\hline & 25 & 13.00 & 14.80 & 6.30 & 16.80 \\
\hline & 30 & 15.00 & 17.00 & 8.00 & 20.00 \\
\hline \multirow{4}{*}{23} & 15 & 13.50 & 15.00 & 7.00 & 15.50 \\
\hline & 20 & 15.50 & 17.30 & 9.00 & 18.80 \\
\hline & 25 & 18.50 & 20.00 & 10.50 & 22.00 \\
\hline & 30 & 22.00 & 23.00 & 11.50 & 24.00 \\
\hline \multirow{4}{*}{27.5} & 15 & 15.00 & 17.00 & 10.00 & 19.00 \\
\hline & 20 & 18.00 & 21.00 & 11.40 & 24.50 \\
\hline & 25 & 23.00 & 27.00 & 15.00 & 30.00 \\
\hline & 30 & 26.50 & 32.00 & 17.00 & 33.50 \\
\hline \multirow{4}{*}{34} & 15 & 18.50 & 23.00 & 14.00 & 25.00 \\
\hline & 20 & 23.00 & 25.50 & 16.00 & 30.50 \\
\hline & 25 & 26.00 & 31.50 & 19.00 & 34.00 \\
\hline & 30 & 30.00 & 33.00 & 23.00 & 36.50 \\
\hline
\end{tabular}

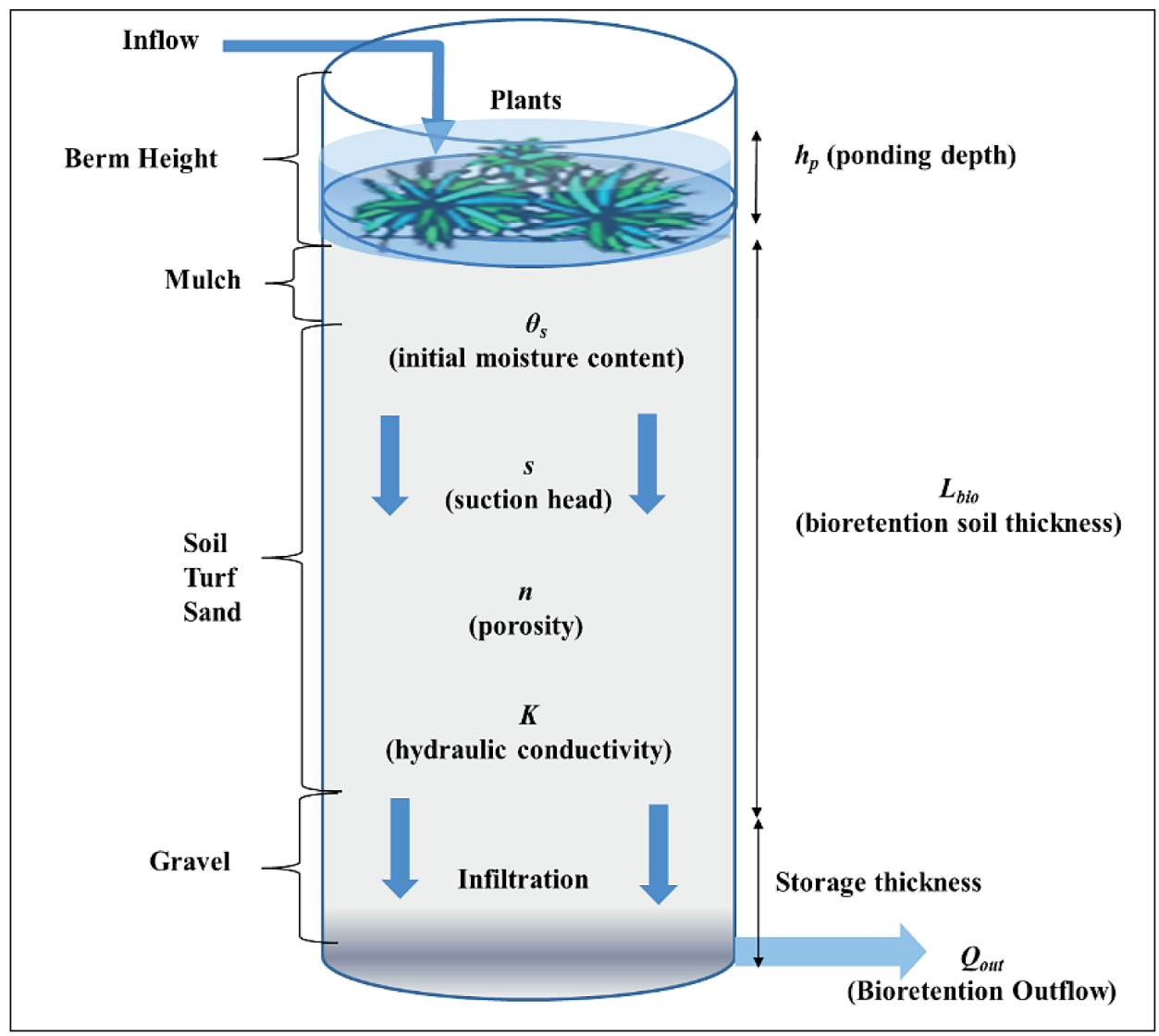

Figure 3

Bioretention modelling principle and parameters used in bioretention columns 


\section{Empirical formula development}

As explained in the previous section, the structure of the empirical formula is developed to predict the peak outflow from a bioretention column. The flow chart of the empirical formula development is shown in Fig. 4. The suggested empirical equation is as follows:

$$
\text { Qpeak }_{\text {out }}=\frac{a \cdot(K)^{b} \cdot\left(s+h_{p}\right)^{c} \cdot\left(n-\theta_{s}\right)^{d}}{\left(L_{\text {bio }}\right)^{e}}
$$

Where $a, b, c, d, e$ are the empirical coefficients, $K$ is the hydraulic conductivity of bioretention column $(L / T), s$ is the suction head $(L), h_{p}$ is the ponding depth $(L), n$ is the porosity, $\theta_{s}$ is the initial moisture content and $L_{b i o}$ is the bioretention soil thickness (L). The empirical coefficients $a, b, c, d$, and $e$ are determined by using optimization algorithms. The difference between the measured and calculated values is minimized using these algorithms. Thus, determination of the empirical coefficients can be considered as an optimization problem.

An objective function has to be defined in optimization methods to obtain the optimum values. In this study, the objective function is defined as follows:

Minimize: $f(x)=\max \left(\%_{\text {error }}\right), \quad x=(a, b, c, d, e)$

$\%_{\text {error }}(i)=\left|\frac{\text { ppeak_out }_{\mathrm{c}}(i)-\text { Qpeak_out }_{\mathrm{m}}(i)}{\text { Qpeak_out }_{\mathrm{m}}(i)}\right| \cdot 100, \quad 1 \leq i \leq n d$

Where, Qpeak_out and Qpeak_out ${ }_{\mathrm{m}}$ are the calculated and measured peak outflow, respectively, $\%_{\text {error }}$ is the absolute per cent error between calculated and measured peak outflow, nd is number of peak flow data.

\section{Optimization methods}

In this paper, 8 different optimization algorithms are used to obtain the optimum empirical coefficients; i.e., particle swarm optimization (PSO), harmony search (HS) algorithm, big bang-big crunch (BB-BC) algorithm, teaching-learning-based optimization algorithm (TLBO), improved teaching-learningbased optimization algorithm (ITLBO), grey wolf optimizer (GWO), mothflame optimization (MFO) algorithm, and Jaya algorithm (JA). PSO developed by Kennedy and Eberhart (1995) is a meta-heuristic algorithm inspired by swarm cooperation of fishes and birds. HS algorithm, developed by Geem et al. (2001), mimics the music improvisation process. BB-BC proposed by Erol and Eksin (2006) is a population-based algorithm from an abstract model of the evolution of the universe. TLBO, proposed by Rao et al. (2011), simulates the classical teaching and learning process. The aim of the algorithm is to improve the average performance of the learners in a class. ITLBO algorithm is a modified version of the TLBO by Rao and Patel (2013). GWO, proposed by Mirjalili et al. (2014), simulates the hunting mechanism of grey wolves. MFO, developed by Mirjalili (2015), is a metaheuristic algorithm inspired by the navigation method of moths in nature called transverse orientation. JA is developed by Rao (2016). The algorithm is similar to TLBO but only has one phase.

The processes of these meta-heuristic optimization algorithms can be summarized in three steps:

- Step 1 - Initializing: An initial population, which contains all initial solutions, is generated randomly and evaluates its objective function values.

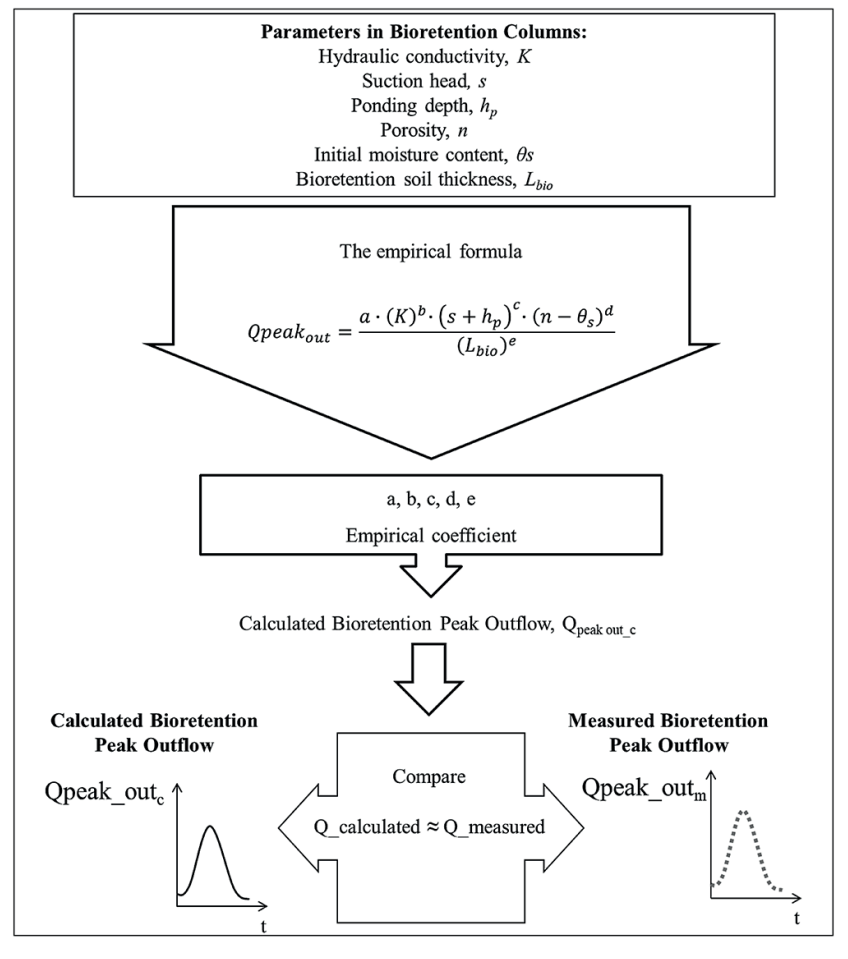

Figure 4

Empirical formula flow chart for bioretention peak outflow

- Step 2 - Generating new solutions: A new solution is generated using the rules of the meta-heuristic algorithms and evaluates the objective value. The new solution is accepted if the objective function value of the new solution is better than that of the old solution.

- Step 3 - Stopping criteria: If stopping criteria is satisfied, optimization process is terminated. The solution with the best objective function value is accepted as the final result. These three steps can be illustrated with a flow chart given in Fig. 5.

\section{RESULTS AND DISCUSSION}

The bioretention peak outflow values are calculated using the empirical equation formulated after determining the empirical coefficients using optimization algorithms. The bioretention outflows are obtained for each bioretention column under 4 artificial rainfall events with different rainfall intensities and duration times. The measured and calculated outflows at the exit of each bioretention column are also presented in Table 4.

In order to determine empirical coefficients $a, b, c, d$, and $e, 8$ different meta-heuristic methods are used. These methods are PSO, HS, BB-BC, TLBO, ITLBO, GWO, MFO, and JA as presented in detail in the previous section. 100 independent runs are performed for each algorithm. As can be seen in Fig. 6, the best error percentage is obtained as $10.9 \%$. The best results for each algorithm are presented in Table 3 . According to these results, the error percentage for all algorithms is around $10.9 \%$. Moreover, 8 different algorithms generated the same solution set as given in the first row of Table 3. This solution also has the minimum objective function values. Therefore, this solution is considered to be the most reliable solution.

After using the optimization process, $a, b, c, d$, and $e$ values are found as $641,1.1,0.6,0.1$, and 0.1 , respectively. 


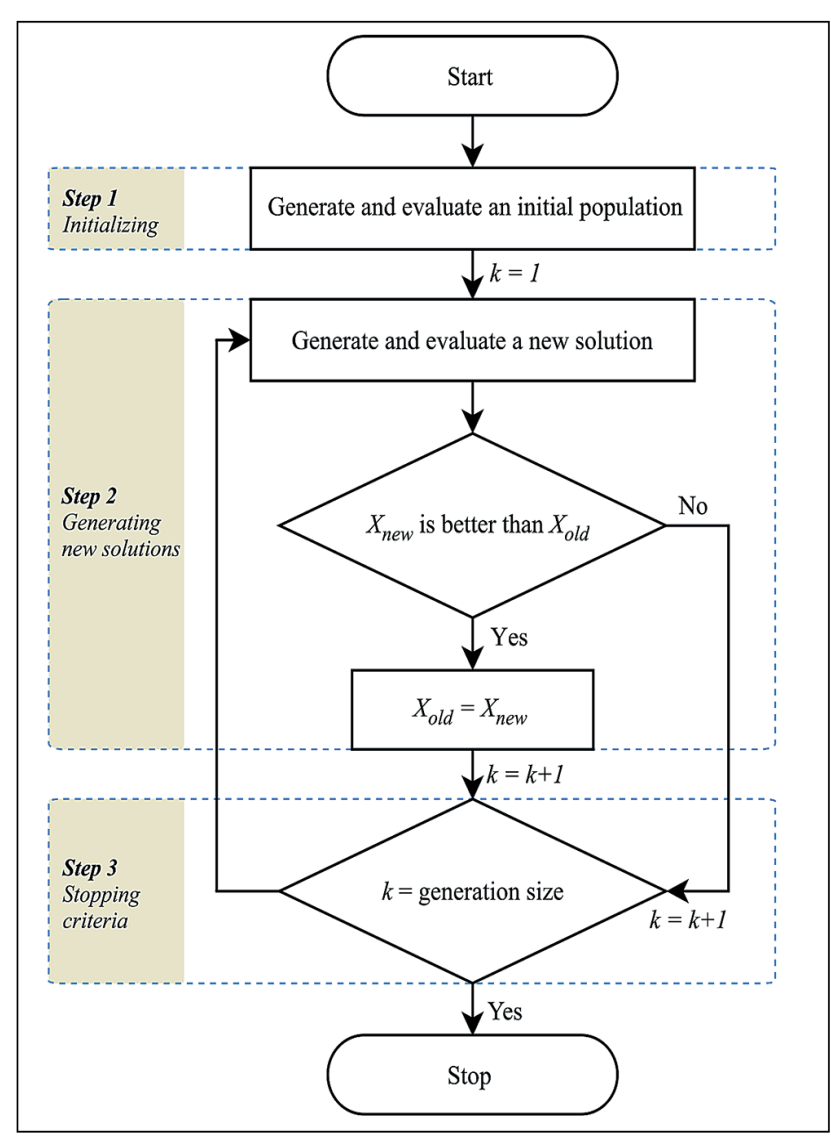

Figure 5

Flow chart of the meta-heuristic optimization algorithms
Thus, the final version of the suggested empirical equation is as follows:

$$
\text { Qpeak }_{\text {out }}=\frac{641 \cdot(K)^{1.1} \cdot\left(s+h_{p}\right)^{0.6} \cdot\left(n-\theta_{s}\right)^{0.1}}{\left(L_{\text {bio }}\right)^{0.1}}
$$

In order to show the performance of the empirical equation, a portion of the measured data in RWB experimental setup, which were not used in the optimization process for the empirical formula development, was employed. The reliability of the empirical equation was verified using this distinct measured dataset by means of calculating absolute per cent errors between the calculated and measured peak outflows of the bioretention system (Table 4). The absolute per cent errors for all bioretention columns are below $10 \%$ for 12 experiments out of 16 experiments and below $20 \%$ for the rest of the experiments. These results show that the empirical formula is successful in representing peak flows out of a bioretention system.

\section{CONCLUSION}

In this study, an empirical equation is developed for the prediction of the peak outflow from a bioretention column by relating it to hydraulic conductivity, suction head, ponding depth, porosity, initial moisture content and bioretention soil thickness. Experimental data obtained in RWB, presented by Gülbaz and Kazezyılmaz-Alhan (2017a), were used in the development of the empirical formula. In order to determine the empirical coefficients of the equation, 8 different meta-heuristic algorithms were employed. Then, the peak of the bioretention outflow was calculated by using

\begin{tabular}{|l|c|c|c|c|c|c|c|c|c|c|c|c|c|c|}
\hline \multicolumn{10}{|c|}{ TABLE 3 } \\
\hline \multicolumn{10}{|c|}{ Optimization results and comparison sorted by error values } \\
\hline$a$ & $b$ & $c$ & $d$ & $e$ & \% error & BB-BC & GWO & IHS & ITLBO & MFO & JA & PSO & TLBO \\
\hline 641 & 1.1 & 0.6 & 0.1 & 0.1 & 10.9059 & $\checkmark$ & $\checkmark$ & $\checkmark$ & $\checkmark$ & $\checkmark$ & $\checkmark$ & $\checkmark$ & $\checkmark$ \\
\hline 892 & 1.1 & 0.5 & 0.1 & 0.1 & 10.9187 & $\checkmark$ & $\checkmark$ & & & $\checkmark$ & $\checkmark$ & $\checkmark$ & $\checkmark$ \\
\hline 1499 & 1.1 & 0.6 & 0.1 & 0.3 & 10.9215 & & & & & & $\checkmark$ & & \\
\hline 980 & 1.1 & 0.6 & 0.1 & 0.2 & 10.9350 & $\checkmark$ & & & & $\checkmark$ & & & $\checkmark$ \\
\hline 1160 & 1.0 & 0.4 & 0.1 & 0.1 & 10.9387 & & $\checkmark$ & & & & $\checkmark$ & & \\
\hline 1360 & 1.1 & 0.4 & 0.1 & 0.1 & 10.9462 & $\checkmark$ & $\checkmark$ & & & $\checkmark$ & $\checkmark$ & & \\
\hline 650 & 1.1 & 0.6 & 0.1 & 0.1 & 10.9795 & & $\checkmark$ & & & $\checkmark$ & & & \\
\hline 942 & 1.1 & 0.5 & 0.1 & 0.1 & 10.9901 & $\checkmark$ & $\checkmark$ & & & & & & \\
\hline
\end{tabular}

\begin{tabular}{|c|c|c|c|c|c|c|c|c|c|c|c|c|c|}
\hline \multicolumn{14}{|c|}{$\begin{array}{l}\text { TABLE } 4 \\
\begin{array}{l}\text { Measured and calculated peak outflows of the bioretention columns and absolute per cent errors } \\
\text { for calculated and measured values }\end{array}\end{array}$} \\
\hline \multirow{3}{*}{$\begin{array}{l}\text { Rainfall } \\
\text { intensity } \\
i(\mathrm{~mm} / \mathrm{h})\end{array}$} & \multirow{3}{*}{$\begin{array}{c}\text { Rainfall } \\
\text { duration } \\
t_{r}(\min )\end{array}$} & \multirow{2}{*}{\multicolumn{4}{|c|}{$\begin{array}{l}\begin{array}{c}\text { Peak outflow measured } \\
\left(\text { Qout }_{\mathrm{m}}\right)(\mathrm{mL} / \mathrm{min})\end{array} \\
\text { Column No }\end{array}$}} & \multirow{2}{*}{\multicolumn{4}{|c|}{$\begin{array}{l}\text { Peak outflow calculated } \\
\left.\text { (Qout })_{c}\right)(\mathrm{mL} / \mathrm{min})\end{array}$}} & \multicolumn{4}{|c|}{$\begin{array}{c}\text { Absolute per cent error } \\
\text { for calculated and measured } \\
\text { peak outflow } \%\end{array}$} \\
\hline & & & & & & & & & & & Col & n No & \\
\hline & & I & II & III & IV & I & II & III & IV & 1 & II & III & IV \\
\hline 16 & 15 & 1145 & 830 & 1460 & 450 & 1054 & 742 & 1346 & 532 & 7.9 & 10.6 & 7.8 & 18.2 \\
\hline 23 & 20 & 1350 & 975 & 1750 & 590 & 1265 & 897 & 1648 & 620 & 6.3 & 8.0 & 5.9 & 5.1 \\
\hline 27.5 & 25 & 1420 & 1035 & 1875 & 681 & 1444 & 1042 & 1851 & 707 & 1.7 & 0.7 & 1.3 & 3.8 \\
\hline 34 & 30 & 1440 & 1100 & 1980 & 775 & 1598 & 1125 & 2119 & 754 & 10.9 & 2.3 & 12.1 & 2.7 \\
\hline
\end{tabular}



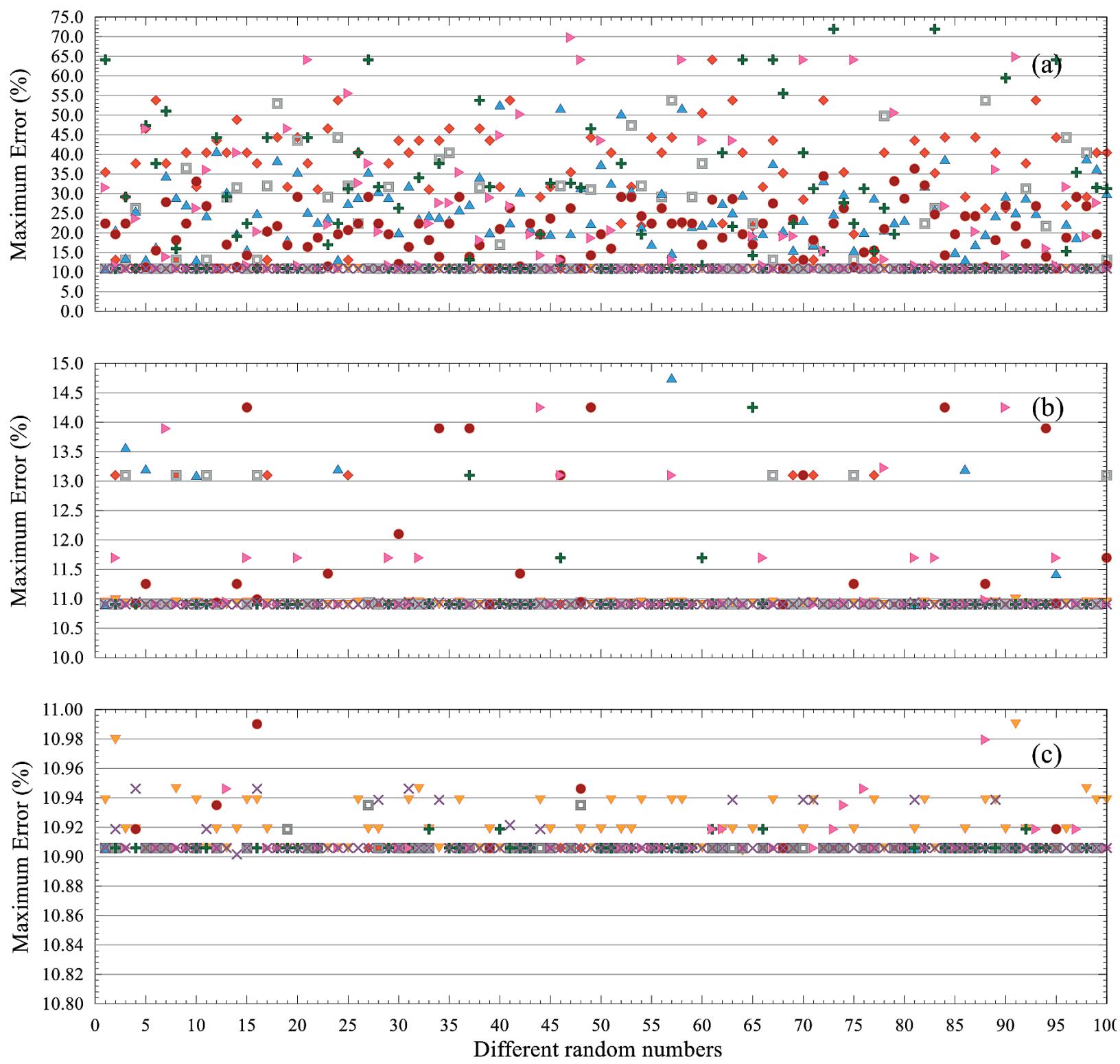

$+\mathrm{PSO} \bullet \mathrm{BB}-\mathrm{BC} \triangle \mathrm{IHS} \quad \square \mathrm{TLBO} \diamond \mathrm{ITLBO} \nabla$ GWO $\triangleright$ MFO $\times \mathrm{JA}$

Figure 6

Maximum error percentage distribution plot for 100 independent runs: (a) all solutions; (b) a more detailed graph of the 10-15\% error range; (c) a more detailed graph of the $10.80-11.00 \%$ error range

the developed formula, and compared with the experimental data. Absolute per cent errors between the measured and calculated peak outflow rates were obtained. The absolute per cent error between calculated and measured peak outflow was smaller than $10 \%$ in 12 experiments out of 16 experiments and below $20 \%$ for the rest of the experiments. Thus, the results of the empirical formula developed herein are in good agreement with the measured data obtained in the RWB experimental setup, and the empirical formula predicts the outflow rate from a bioretention system reasonably well.

The empirical formula can be used in prediction of the peak outflow from a bioretention column and evaluation of the hydrological performance of different bioretention designs.
SWMM5 options for a bio-retention cell could incorporate the use of a similar empirical formula to the one developed in this study, allowing the user to enter the coefficients specific to their case where similar experimental setups have been conducted in a watershed. This study attempts to determine the peak of the bioretention outflow hydrograph, since prediction of peak flow is helpful to manage flood events. Measurement or estimation of peak flow is necessary in order to evaluate the peak flow reduction performance of bioretention. Future research should include developing the empirical formula to obtain the bioretention outflow hydrograph using meta-heuristic optimization algorithms. Moreover, mathematical models can be developed to explain the behaviour of bioretention systems in pollution removal. 


\section{ACKNOWLEDGEMENTS}

This work was supported by Scientific Research Projects Coordination Unit of Istanbul University, Project number BEK-2017-26748. The writers would like to thank Scientific Research Projects Coordination Unit of Istanbul University for their support in undertaking this work. The authors would like to express their gratitude to the anonymous reviewers and the editor for their excellent suggestions which strengthened the paper.

\section{REFERENCES}

BIRCH GF, MATTHAI C, FAZELI MS and SUH JY (2004) Efficiency of a constructed wetland in removing contaminants from stormwater. Wetlands 24 (2) 459-466. https://doi. org/10.1672/0277-5212(2004)024[0459:EOACWI]2.0.CO;2

BROWN RA and HUNT WF (2011) Underdrain configuration to enhance bioretention exfiltration to reduce pollutant loads. J. Environ. Eng. 137 (11) 1082-1091. https://doi.org/10.1061/(ASCE) EE.1943-7870.0000437

DAVIS AP (2008) Field performance of bioretention: Hydrology impacts. J. Hydrol. Eng. 13 (2) 90-95. https://doi.org/10.1061/ (ASCE)1084-0699(2008)13:2(90)

DEBUSK K and WYNN T (2011) Storm-water bioretention for runoff quality and quantity mitigation. J. Environ. Eng. 137 (9) 800-808. https://doi.org/10.1061/(ASCE)EE.1943-7870.0000388

ENDRENY T and COLLINS V (2009) Implications of bioretention basin spatial arrangements on stormwater recharge and groundwater mounding. Ecol. Eng. 35 (5) 670-677. https://doi. org/10.1016/j.ecoleng.2008.10.017

EROL OK and EKSIN I (2006) A new optimization method: Big Bang-Big Crunch. Adv. Eng. Softw. 37 (2) 106-111. https://doi. org/10.1016/j.advengsoft.2005.04.005

GEEM ZW, KIM JH and LOGANATHAN GV (2001) A new heuristic optimization algorithm: Harmony search. Simulation 76 (2) 60-68.

GÜLBAZ S and KAZEZYILMAZ-ALHAN CM (2017a) Experimental investigation on hydrologic performance of LID with rainfallwatershed-bioretention system. J. Hydrol. Eng. 22 (1) D4016003.

GÜLBAZ S and KAZEZYILMAZ-ALHAN CM (2017b) Hydrological model of LID with rainfall-watershed-bioretention system. Water Resour. Manage. 31 (6) 1931-1946.

GÜLBAZ S and KAZEZYILMAZ-ALHAN CM (2017c) An evaluation of hydrologic modeling performance of EPA SWMM for bioretentions. Water Sci. Technol. 76 (11-12) 3035-3043.

GÜLBAZ S and KAZEZYILMAZALHAN CM, NASIRZADEHDIZAJI R and DIKICI M (2017) A calibrated hydrological model for Alibeyköy Watershed in Istanbul, Turkey incorporating LID implementation. Fresenius Environ. Bull. 26 6112-6120.

HATT BE, FLETCHER TD and DELETIC A (2009) Hydrologic and pollutant removal performance of stormwater biofiltration systems at the field scale. J. Hydrol. 365 (3-4) 310-321.

HUNT W, JARRETT A, SMITH J and SHARKEY L (2006) Evaluating bioretention hydrology and nutrient removal at three field sites in North Carolina. J. Irrig. Drain. Eng. 132 (6) 600-608. https://doi. org/10.1061/(ASCE)0733-9437(2006)132:6(600)
HUNT W, SMITH J, JADLOCKI S, HATHAWAY J and EUBANKS $\mathrm{P}$ (2008) Pollutant removal and peak flow mitigation by a bioretention cell in urban Charlotte, N.C. J. Environ. Eng. 134 (5) 403-408. https://doi.org/10.1061/(ASCE)0733-9372(2008)134:5(403)

KENNEDY J and EBERHART R (1995) Particle swarm optimization. In: Proceedings of ICNN'95 - International Conference on Neural Networks, 27 November-1 December 1995, Perth, WA, Australia.

LIU J, SAMPLE DJ, BELL C and GUAN Y (2014) Review and research needs of bioretention used for the treatment of urban storm water. Water 6 (4) 1069-1099.

LI H and DAVIS AP (2009) Water quality improvement through reductions of pollutant loads using bioretention. J. Environ. Eng. 135 (8) 567-576. https://doi.org/10.1061/(ASCE) EE.1943-7870.0000026

LI H, SHARKEY LJ, HUNT WF and DAVIS AP (2009) Mitigation of impervious surface hydrology using bioretention in North Carolina and Maryland. J. Hydrol. Eng. 14 (4) 407-415. https://doi. org/10.1061/(ASCE)1084-0699(2009)14:4(407)

MAKROPOULOS C and BUTLER D (2010) Distributed water infrastructure for sustainable communities. Water Resour. Manage. 24 (11) 2795-2816. https://doi.org/10.1007/s11269-010-9580-5

MIRJALILI S (2015) Moth-flame optimization algorithm: A novel nature-inspired heuristic paradigm. Knowledge-Based Syst. 89 228-249. https://doi.org/10.1016/j.knosys.2015.07.006

MIRJALILI S, MIRJALILI SM and LEWIS A (2014) Grey Wolf Optimizer. Adv. Eng. Softw. 69 46-61.

OLSZEWSKI J and DAVIS A (2013) Comparing the hydrologic performance of a bioretention cell with predevelopment values. J. Irrig. Drain. Eng. 139 (2) 124-130. https://doi.org/10.1061/(ASCE) IR.1943-4774.0000504

RAO RV (2016) Jaya: A simple and new optimization algorithm for solving constrained and unconstrained optimization problems. Int. J. Ind. Eng. Comput. 7 19-34.

RAO RV and PATEL V (2013) An improved teaching-learning-based optimization algorithm for solving unconstrained optimization problems. Sci. Iranica 20 (3) 710-720.

RAO RV, SAVSANI VJ and VAKHARIA DP (2011) Teaching-learningbased optimization: A novel method for constrained mechanical design optimization problems. Comput.-Aided Design 43 (3) 303-315.

ROSSMAN LA (2010) Storm Water Management Model, User's Manual, Version 5. EPA/600/R-05/040. Water Supply and Water Resources Division National Risk Management Research Laboratory, United States Environmental Protection Agency, Cincinnati, Ohio.

SIGMON L, HOOPES S, BOOKER M, WATERS C, SALPETER K and TOUCHETTE B (2013) Breaking dormancy during flood and drought: sublethal growth and physiological responses of three emergent wetland herbs used in bioretention basins. Wetlands Ecol. Manage. 21 (1) 45-54. https://doi.org/10.1007/s11273-012-9278-y

YANG XS (2010) Engineering Optimization: An Introduction with Metaheuristic Applications. John Wiley \& Sons, New Jersey.

YANG HB, DICK WA, MCCOY EL, PHELAN PL and GREWAL PS (2013) Field evaluation of a new biphasic rain garden for stormwater flow management and pollutant removal. Ecol. Eng. $\mathbf{5 4}$ 22-31. 